\title{
Governance Analysis of St Anne Marine National Park, Seychelles
}

Lucy M. Cockerell*, Peter J. S. Jones

Dept. of Geography, Pearson Building, University College London (UCL), Gower Street, London, WC1E 6BT, UK

* Corresponding author: 34b Leamington Road Villas, W11 1HT, London, UK. E-mail addresses:

lucy.cockerell.17@alumni.ucl.ac.uk (L.M. Cockerell), p.j.jones@ucl.ac.uk (P.J.S. Jones).

Declarations of interest: none

\begin{abstract}
The aim of this paper is to explore the governance effectiveness of St Anne Marine National Park (SAMNP), Seychelles. By collecting qualitative data through interviews and ethnographic observations from different constituencies in May and June 2018, the Marine Protected Area Governance (MPAG) analysis framework was applied. This case study revealed that the site is governed by a parastatal organisation (SNPA) and its Board through a largely ineffective top-down, government-led approach. The primary threats to the success of the park that fall within the purview of MPA (marine protected area) governance, are poaching, coastal development and unsustainable tourism, with a clear lack of state capacity, political will and capacity for enforcement as the key drivers undermining equitable and effective governance. Additionally, the study revealed a lack of community involvement in decision-making processes, resulting in a lack of sufficient participation and knowledge incentives, which reflects the need for the inclusion of more bottom-up governance approaches. This study contributes to the broader conceptual framework by supporting the understanding that a combination of governance approaches are needed to achieve MPA objectives and resilience. The governance structure coupled with the identified conflicts and many additional driving forces and constraints discussed throughout, are obstructing the achievement of strategic MPA objectives and severely undermining effectiveness. Suggestions for improvement are therefore explored as significant governance modifications are clearly needed. Since the completion of this research, significant advances have been made to the governance of SAMNP and where relevant these have been noted briefly throughout the paper.
\end{abstract}

Keywords: Governance analysis; Marine protected areas; MPA; Environmental management; Effectiveness

\section{Highlights}

$>$ Poaching, coastal development and unsustainable tourism are the main conflicts.

$>$ SAMNP is governed through a largely ineffective top-down, government-led approach.

$>$ Numerous incentives need strengthening to enhance governance effectiveness.

This is the authors' version of the final accepted Marine Policy manuscript. Elsevier $(2020$. This manuscript version is made available under the CC-BY-NC-ND 4.0 license.

https://doi.org/10.1016/j.marpol.2020.103912

\section{Creative
commons}

Cockerell, L.M. and Jones, P. J. S. (in press) Governance Analysis of St Anne Marine National Park, Seychelles. Marine Policy, 103912. https://doi.org/10.1016/j.marpol.2020.103912. One of 20 papers in a special section on 28 case studies on MPA Governance. 


\section{Introduction}

The Seychelles comprises 115 granite and coral islands over an Exclusive Economic Zone (EEZ) of 1.3 million $\mathrm{km} 2$, about 3000 times the size of its land territory [1]. The nation is an internationally recognised biodiversity hotspot, supporting some of the world's most pristine and diverse marine ecosystems, but since the colonisation in the late 18th century, marine species have been heavily exploited and some eradicated [2]. Extensive fishing down the food chain resulted in the destabilisation of marine ecosystems, making Seychellois quick to recognise the importance of taking conservation into consideration alongside economic development and the sustainable use of natural resources [3]. Today the Seychellois are extremely reliant on marine ecosystems as tourism and fishing, i.e. the 'Blue Economy', are the primary drivers of socioeconomic development, making sound management of marine ecosystems of paramount national importance [4]. A large percentage of Seychellois territory has therefore been set aside as protected areas to safeguard resources, through the commitment of the government, international organisations, NGOs and the private sector. However, the designation alone is not effective unless the sites are managed in a way that supports the achievement of the conservation objectives, and as the drive for assembling revenue continues to supersede environmental concerns and the nation faces characteristic small island developing state (SIDS) constraints, effective governance of MPAs in the Seychelles has proved challenging [5-7].

SAMNP was designated in 1973 by the Republic of the Seychelles due to its richness of aquatic fauna and its proximity to the capital. It was not only the Seychelles' first MPA, but also the first in the Western Indian Ocean. Covering an area of over $14 \mathrm{~km} 2$, the site is an IUCN category II, i.e. National Park (with a no-takezone), located in the country's 'Inner Islands' [Figure 1]. SAMNP protects marine habitats and a large variety of fish, plants and species characteristic of the area, and is also a shark pupping ground and a turtle nesting site. Nowadays tour operators provide excursions to SAMNP, but before designation, the site was only inhabited by local Seychellois and used as traditional fishing grounds. SAMNP also provides for cultural, educational and scientific opportunities [8]. The marine national park (MNP) is located $5 \mathrm{~km}$ east of Victoria on Mahé, which is the economic, political and administrative centre, accommodating about $90 \%$ of the national population [1], making it among the most accessible islands in the nation. SAMNP encompasses six islands [Figure 2] and protects their shorelines up to the high-water mark. Some islands are uninhabited while others house a small number of MPA residents, restaurants and resorts. St Anne is the biggest island in the MNP and was where the first settlers arrived in the Seychelles in 1770. SAMNP is therefore of significant historical and cultural heritage. The island has since served as a Royal Marines base during World War II, a whaling activity area in the 19th century, the SNPA HQ until 2001, as well as a boarding school. Today a luxury resort on St Anne Island is expanding, while others are being developed [8].

The information for this paper has been gleaned from interviews with representatives from different constituencies, in combination with qualitative data gathered from ethnographic observations, informal discussions, scientific reports, websites, newspaper articles, social media sites and official documents, and is to the best of the author's knowledge, true and accurate. 26 in-depth semi-structured interviews (15-120 min long) were conducted in the capital Mahé over three weeks in May and June 2018. In order to gather a broad spectrum of inputs from interviewees to explore different perspectives on the governance of SAMNP, respondents included fishermen, university professors, SNPA staff, tourism employees, Cerf island residents, marine biologists, divers, researchers, SAMNP rangers, SAMNP resort staff, conservation NGOs, government officials, and members of the marine police unit. Purposive sampling was used to recruit interviewees, whereby participants within a certain criterion i.e. individuals affecting, affected, or simply knowledgeable about SAMNP were approached. Interviewees were contacted via email, websites and social media platforms prior to arrival to the Seychelles, but due to a low response rate, the most effective technique turned out to be door-knocking and telephoning potential participants upon arrival. Snowballing was also used whereby individual contacts helped recruit additional contacts and as the name implies, momentum was gained and an abundance of informants was formed. All information derived from interviews and other

Cockerell, L.M. and Jones, P. J. S. (in press) Governance Analysis of St Anne Marine National Park, Seychelles. Marine Policy, 103912. https://doi.org/10.1016/j.marpol.2020.103912. One of 20 papers in a special section on 28 case studies on MPA Governance. 
ethnographic approaches is reported anonymously in this paper, in order to protect the anonymity of interviewees and in keeping with University College London's research ethics requirements. This study is based on the first author's MSc dissertation which was completed in September 2018, and is one of several case studies applying the marine protected area governance (MPAG) analysis framework in this special section, the rationale and methodology being described and justified in detail in the introductory and discussion paper [9].

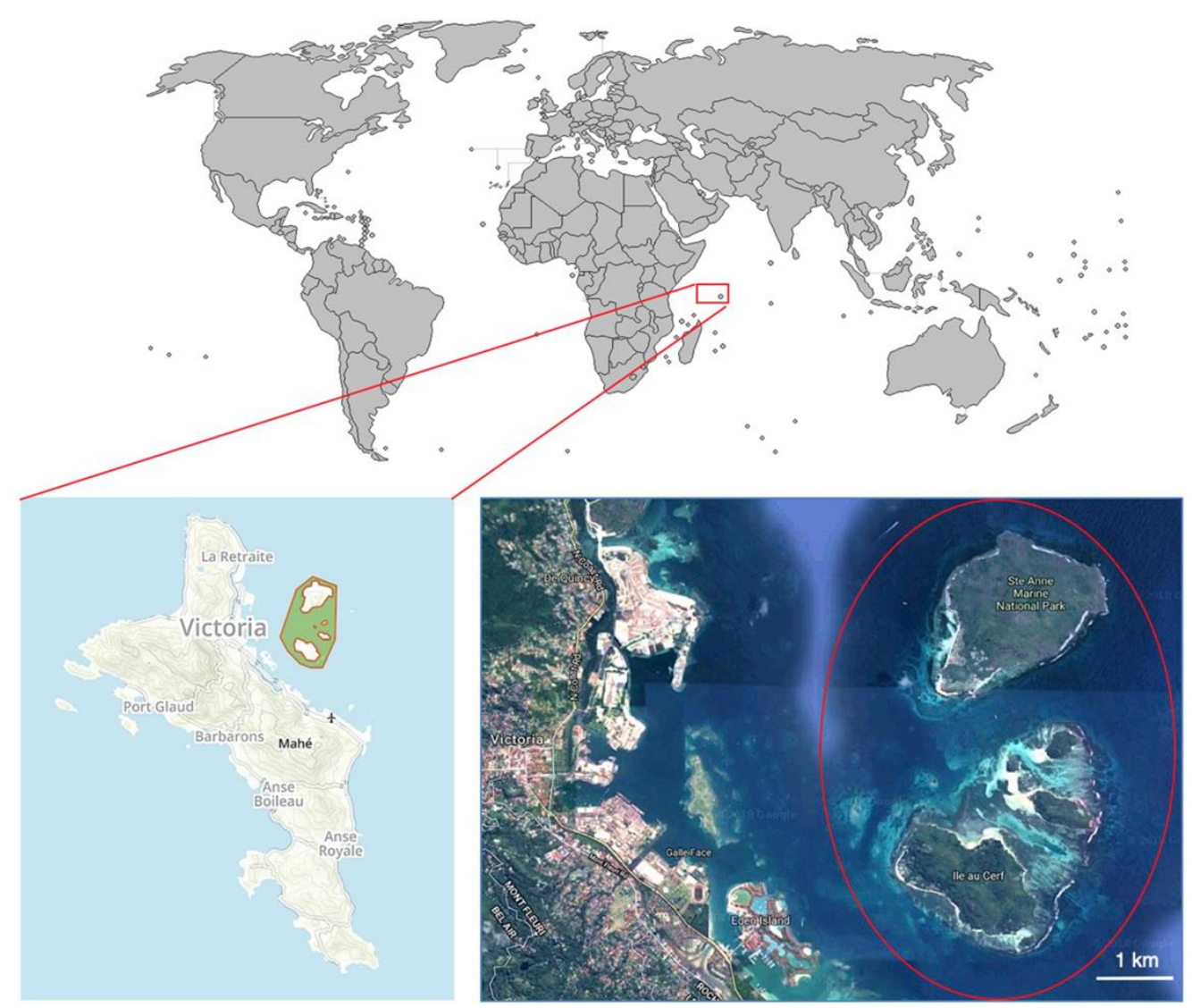

Figure 1. SAMNPs location (Source: modified from Wikipedia 2018, BlankMap-World-v4-Borders.svg, Wiz9999/CC BY-SA (http://creativecommons.org/licenses/b y-sa/3.0/) https://commons.wikimedia.org/wiki/File:BlankMap-World-v4-Borders.png, Protected Planet, Mapbox, 2018, UNEP-WCMC, IUCN and WDPA Cambridge, UK, www. protectedplanet.net, modified from Google Maps Maxar Technologies 2018).

\section{Context}

The Seychelles is the smallest African country, with the second highest GDP per capita [1] [Table 1]. It recently gained high-income country status but still possesses most of the characteristic constraints of a SIDS (Small Island Developing State) in terms of its isolated location, limited human and economic resources, weak state performance, high national poverty rate and dependence on tourism, high income inequality and susceptibility to natural disasters, which all pose threats to its economy $[10,11]$. Nonetheless, the Seychelles' tourism sector has proved buoyant, reaching a record high of over 360,000 visitors in 2018 , which is 3,5 times the resident population [12]. The tourism sector employs ca $26 \%$ of the active workforce and accounts for approximately $55 \%$ of GDP, while ca $15 \%$ of the population depend on fishing or fishing-related activities for their livelihoods, making these sectors the main contributors to the national economy [1]. As such, one of

Cockerell, L.M. and Jones, P. J. S. (in press) Governance Analysis of St Anne Marine National Park, Seychelles. Marine Policy, 103912. https://doi.org/10.1016/j.marpol.2020.103912. One of 20 papers in a special section on 28 case studies on MPA Governance. 
the main challenges the Seychellois government is currently facing is to implement long-term strategies to increase resilience to climate change without weakening economic growth.

Table 1 Context of SAMNP.

\begin{tabular}{|l|l|l|l|}
\hline GDP Per Capita & $\begin{array}{l}\text { US\$29.300 (2017, } \\
70 / 228)[1]\end{array}$ & State Capacity & $\begin{array}{l}0.32(61.39 \%)(2016) \\
{[2]}\end{array}$ \\
\hline GDP Growth Rate & $5.3 \%(2017,43 / 224[1]$ & $\begin{array}{l}\text { Human Development Index } \\
\text { (HDI) }\end{array}$ & $\begin{array}{l}0.797(2017,62 / 189) \\
{[13]}\end{array}$ \\
\hline
\end{tabular}

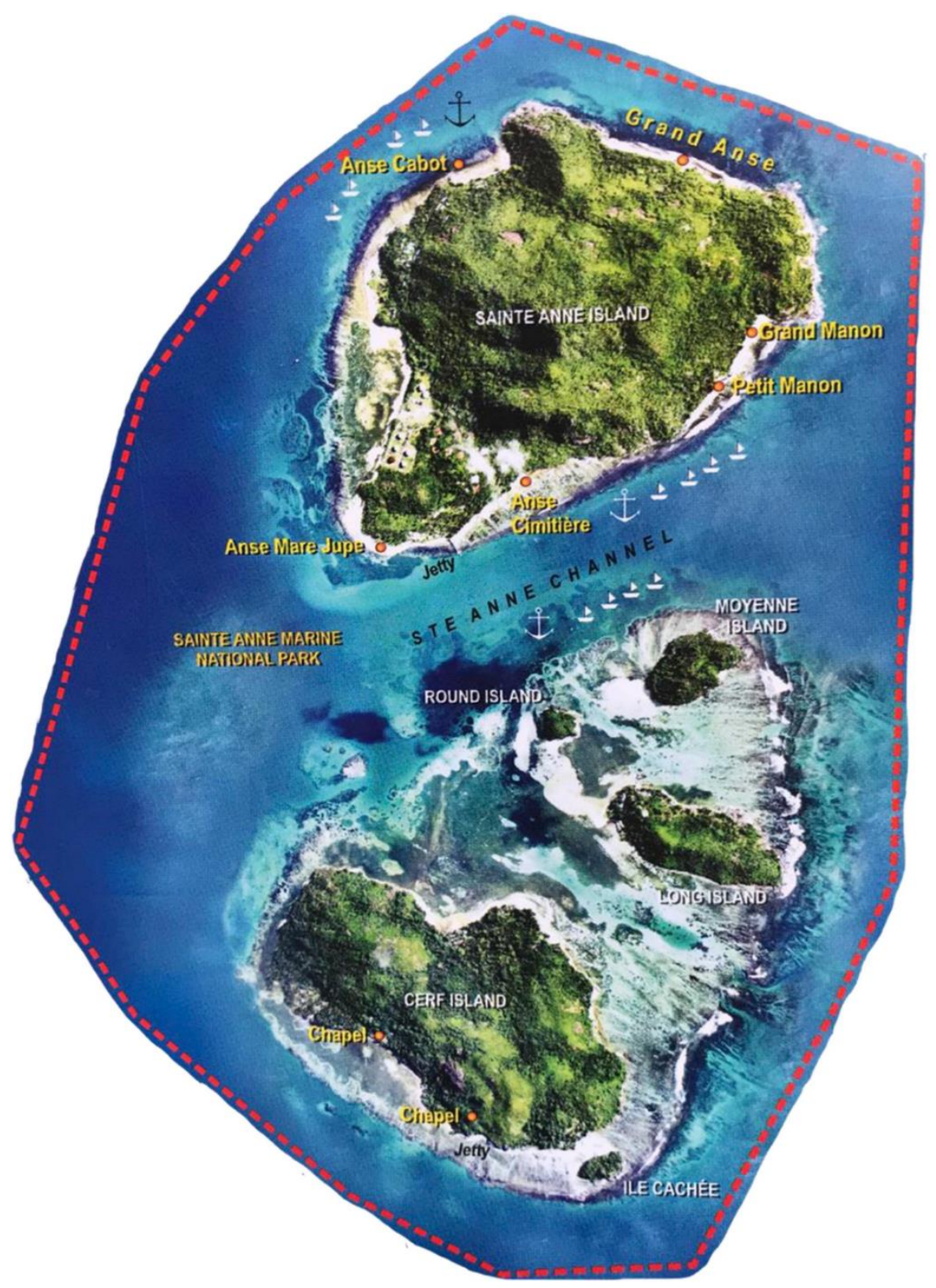

Figure 2. Overview of SAMNP (Source: SCMRT brochure).

Cockerell, L.M. and Jones, P. J. S. (in press) Governance Analysis of St Anne Marine National Park, Seychelles. Marine Policy, 103912. https://doi.org/10.1016/j.marpol.2020.103912. One of 20 papers in a special section on 28 case studies on MPA Governance. 
Table 2 SAMNP's objectives.

\begin{tabular}{|l|l|}
\hline Conservation & Operational \\
\hline $\begin{array}{l}\text { Conserve marine biodiversity and } \\
\text { marine environments (particularly } \\
\text { coral reefs, sand flats and sea grass } \\
\text { beds) from harmful disturbances. }\end{array}$ & $\begin{array}{l}\text { Promote effective management of the area and its shores, while } \\
\text { managing the uses of the park for the enjoyment of the public. }\end{array}$ \\
& $\begin{array}{l}\text { Facilitate and increase responsible tourism practices that meet } \\
\text { the expectations of visitors. } \\
\text { Demonstrate the benefits of protected areas to the Seychellois, } \\
\text { its people and its economy. }\end{array}$ \\
\hline
\end{tabular}

\section{Objectives}

A first official management plan is currently in the process of being developed for SAMNP, and a public meeting will be held in the spring 2020, to present the plan to the public prior to adoption. The site's conservation aims according to interviewees, are nonetheless seemingly as presented in Table 2 .

\section{Drivers/conflicts}

The main external threats, largely beyond the ability of park authorities to influence, were recreational use by local Seychellois residents, pollution and coastal runoff, while climate change must also be noted as a pervasive wider scale threat. Firstly, in terms of recreational use by locals, picnickers bring generators and loudspeakers to SAMNP's beaches and party loudly during weekends. Property trespassing, substance abuse, fires and littering are also common. Locals drive jet-skis and power boats at high speeds, which is dangerous to swimmers and disturbs fauna, MPA residents and hotel guests. Secondly, garbage enters SAMNP both from Mahé and overseas. The amount of litter surpasses the ability of beach cleaning efforts to remove, while traffic pollution from Victoria port, tourism vessels and nearby shipping lanes are also a growing concern due to the risk of e.g. oil and cargo spillage. Thirdly, organic waste, sewage discharges and solid waste enter the site from both inside SAMNP and from canals and rivers on Eastern Mahé, threatening the park's marine environment. There is also a landfill close to the site. However, insufficient research has been conducted on coastal runoff in the area to understand its impacts on SAMNP. Lastly, the impacts of climate change are immense - the $1998 \mathrm{El}$ Niño event damaged up to $90 \%$ of the nation's corals, followed by the 2004 tsunami and another bleaching event in 2016 where between 69 and $99 \%$ of all surveyed corals were impacted, which resulted in a subsequent $50 \%$ reduction of hard coral cover [14-16]. Interviewees were concerned about this pervasive wider-scale threat especially as models predict that rising sea surface temperatures driven by climate change are increasing the frequency and severity of coral bleaching events in the central Indian Ocean within the timescale necessary for reef recovery, implying that the future prospects for coral reefs in the Seychelles are increasingly uncertain [17]. Furthermore, regarding the risk of more frequent bleaching events, studies have revealed no evidence of no-take zones (NTZs) showing enhanced resilience to declines in corals and fish abundance due to coral bleaching, in comparison with fished areas $[18,19]$. Interviewees identified the three primary conflicts to SAMNP as poaching, coastal development and unsustainable tourism practices, with a lack of state capacity, political will and capacity for enforcement as the leading drivers. These are among the most frequently cited threats to MPAs $[20,21]$.

Cockerell, L.M. and Jones, P. J. S. (in press) Governance Analysis of St Anne Marine National Park, Seychelles. Marine Policy, 103912. https://doi.org/10.1016/j.marpol.2020.103912. One of 20 papers in a special section on 28 case studies on MPA Governance. 


\subsection{Poaching}

As with many MPAs in Eastern Africa, SAMNP has experienced difficulties in restricting fishing activities [22]. Fish (primarily rabbitfish, Siganidae and parrotfish, Scaridae), turtles, octopi and sharks are frequently poached by trawling and line-fishing, which has long been the biggest threat to SAMNP as it leads to biodiversity impacts. Poaching in MPAs is typically considered attractive due to the higher fish density in the area [23], and in this case also because of the area's shallowness and proximity to Victoria. SAMNP inhabitants' fish from Cerf Island with a 'this is my land and therefore I can fish here' attitude. One MPA resident explained how he is too old to fish beyond SAMNP borders, stating that "... going to Victoria to buy fish would be a nuisance. You need to buy fuel and take the bus and the fish in the market is becoming increasingly expensive". This reasoning signifies poverty and a means of survival, whereas poachers also fish in SAMNP because they are aware of the low risk of detection, i.e. the lack of effective enforcement coupled with insignificant penalties for deterrence. This signifies deeper underlying societal issues concerning peoples' thrill and pride in breaching legislations - "a wild west problem" as one interviewee put it. In addition, recreational fishing in the Seychelles does not require a fishing license, meaning that if desired, poaching is easy for anyone to resort to.

According to Bergseth (2018), ensuring effective management through high compliance, requires transitioning beyond the conventional views of enforcement, and instead consider how information is processed, reconceptualize how people behave, and design regulations to shape behaviour [24]. It has thus been recognised that resistance to conservation measures can arise because MPA benefits may be unclear to society $[25,26]$. Poachers also know that penalties are insignificant and that the process from capture to prosecution is long and highly unlikely. Despite countless interceptions since SAMNP's designation, very few cases have been followed through due to Mahé's small population being highly networked and full of extended family-ties and political connections, making it easy for powerful acquaintances to dismiss cases and make evidence 'disappear'. Moreover, poachers are often dangerous, seeking vengeance on informants, resulting in a 'not worth it' attitude towards reporting transgressions. One interviewee explained seeing poachers enter SAMNP daily, catching sharks and turtles, "... I always used to call the rangers but they themselves are scared so they tell the poachers who informed them, so the poachers sink my boat for vengeance! I eventually gave up calling. Now when I see poachers I scream and wave my machetes to scare them off, but if the park were properly managed, I wouldn't have to deal with this madness". Numerous interviewees described similar situations and explained how "it is all about contacts - rangers have deals with certain residents". Rangers patrol SAMNP in two boats and are occasionally assisted by the marine police. They arrive and leave when they deem appropriate, acknowledging that poachers enter SAMNP as soon as they leave. Furthermore, there are currently only two or three rangers patrolling SAMNP while there should be eight, which increases the burden on rangers who are already overloaded with work, lacking time to conduct research or seize perpetrators, as they are too busy collecting entrance fees. Low salaries, odd working hours, remote placements, old equipment, little respect and too many errands to run, makes the position relatively unattractive. It is also alleged that some rangers themselves engage in transgressions e.g. mis-appropriating entrance fees, resulting in the leakage of benefits, whilst some rangers are reported to have established informal agreements with select locals, turning a blind-eye to certain illegal activities. It is common that rangers ignore non-compliance not only due to fear of perpetrators, but also because they consider offences unimportant and prosecution unnecessary [27]. Poachers should be fined, but this rarely, if ever, happens due to the lack of enforcement capacity, inadequate rangers, facilities and funding, lack of recognition of benefits and regulations and lack of an effective juridical system to pursue penalties for deterrence. However, it has been shown that effective enforcement of MPAs can reduce poaching, implying that prosecution is essential to successful NTZs $[28,29]$. SNPA should thus investigate establishing a visitor centre in SAMNP, where rangers could be based 24/7 to facilitate night-patrols, and visitor facilities and information could also be provided. Appointing honorary wardens and implementing technological advances e.g. drones, could additionally improve surveillance.

Cockerell, L.M. and Jones, P. J. S. (in press) Governance Analysis of St Anne Marine National Park, Seychelles. Marine Policy, 103912. https://doi.org/10.1016/j.marpol.2020.103912. One of 20 papers in a special section on 28 case studies on MPA Governance. 


\subsection{Coastal development}

The nation's favourable growth prospects offer attractive opportunities to continue satisfying tourism demands, by developing new infrastructure through coastal development and land reclamation, both inside SAMNP and adjacent to it. Land-based human activities are threatening SAMNP's marine ecosystems and biodiversity, an example being the development of the man-made Eden Island which has been constructed over the past fifteen years. Eden Island is built on a reclaimed coral reef, comprising of a marina, hotels, restaurants and luxury villas [Figure 3]. The environmental impacts on SAMNP from the development's construction include coral reef destruction, coastal erosion, changed currents and sediment deposition on corals and sea grass beds, both of which should be protected in SAMNP. Interviewees explained that the area used to be occupied by mangroves and corals, but that now, due to the lack of natural protection, waves bounce off the constructions and stir up the currents which bring in debris to SAMNP. Interviewees reported a noticeable deterioration in marine life and coral health, including reduced fish abundance and diversity, since Eden Island was built, claiming that the altered currents and sand patterns have impacted marine habitats and species. There is also strong anecdotal evidence that land reclamation on Mahé has destroyed critical habitats, causing the collapse of the white-streaked grouper (Epinephelus ongus) and the marbled parrotfish (Leptoscarus vaigiensis) [2]. However, no baseline analyses were conducted prior to the development, making it difficult to provide scientific evidence to authenticate the observed degradation. Informal discussions with diving operators and fishermen further verified a visible loss of species diversity and abundance in SAMNP during the past decade, the general opinion thus being that conservation objectives have not been met. Interviewees explained that old fishermen tell stories about how rich SAMNP used to be and the variety of species and spawning areas that could be found there. There is therefore anecdotal evidence that coastal development has resulted in a noticeable deterioration in marine biodiversity and ecosystem health.

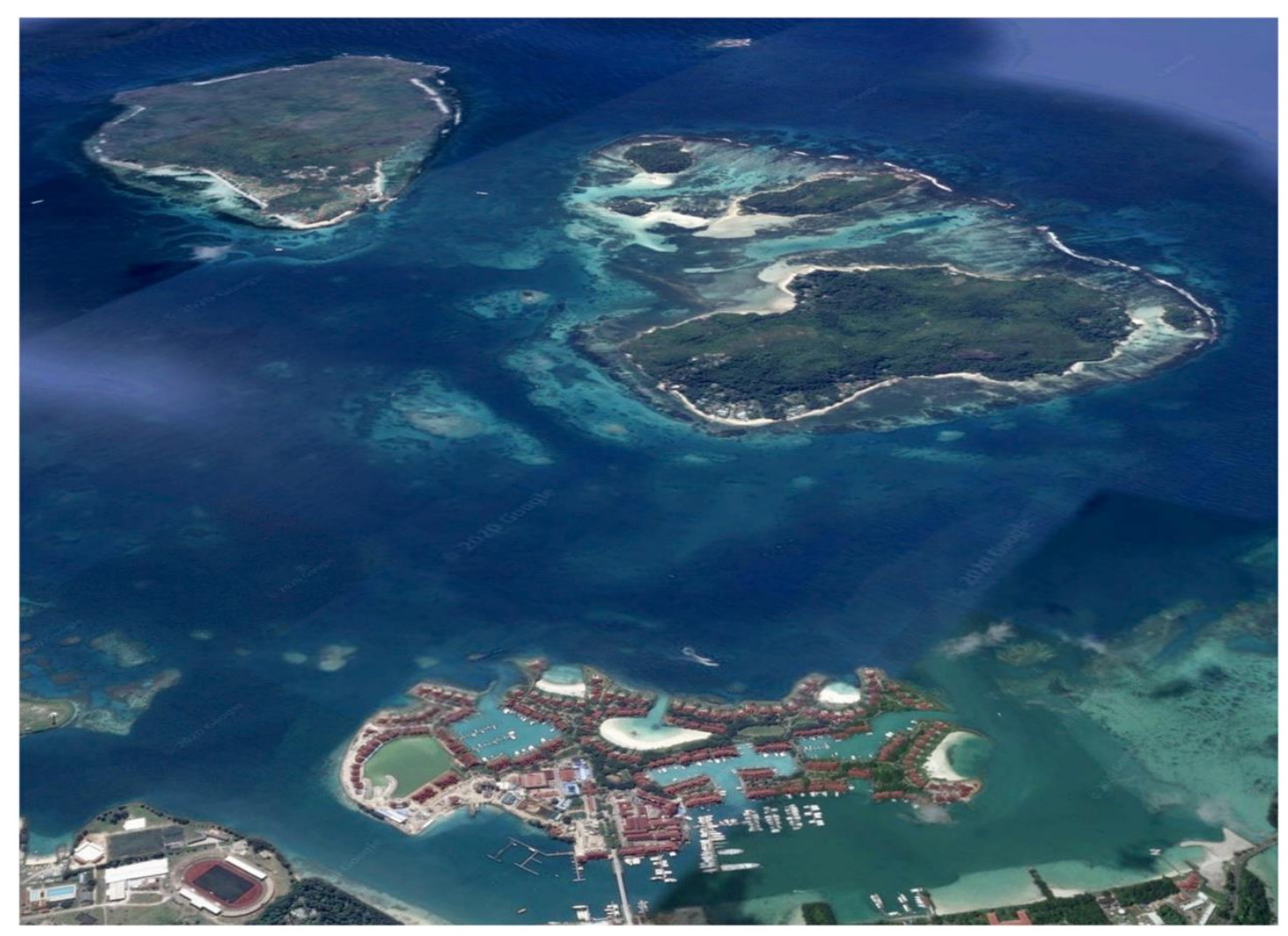

Figure 3. Eden Island with SAMNP in the background (Source: Google Earth Maxar Technologies 2020).

Cockerell, L.M. and Jones, P. J. S. (in press) Governance Analysis of St Anne Marine National Park, Seychelles. Marine Policy, 103912. https://doi.org/10.1016/j.marpol.2020.103912. One of 20 papers in a special section on 28 case studies on MPA Governance. 
There are increasing applications from MPA residents and hoteliers to construct jetties, villas and hotels inside SAMNP, and due to the lack of recent comprehensive research, it remains unclear whether the site has the carrying capacity to sustain the proposed developments and what the environmental impacts would be. Nevertheless, the construction of numerous large hotel projects has been approved, which will likely exert significant pressure on waste management, sewage, electricity and water supply, further exacerbating environmental degradation in the vicinity. Increased development was of great concern among interviewees who argued that eco-friendly activities should instead be promoted. Interviewees also explained that the Environmental Impact Assessments (EIAs) conducted prior to coastal developments, have never taken local opinions into consideration, making the EIA process appear very flawed. Alas, SNPA has little influence over these matters as the islands inside SAMNP are state-owned, privately-owned or leased to hotel developers. The findings therefore resonate with the argument that "... marine protected areas are acutely vulnerable to current trends in land use and development in Seychelles" [7].

\subsection{Tourism}

Tourism is vital to the Seychelles economy and will likely continue to be, as visitor numbers to the country increase every year, with approximately $40 \%$ visiting a SNPA site during their stay [30]. Globally, tourism has proven to negatively impact ecological features of protected areas [31] and similarly, interviewees argued that tourism is one of the biggest threats to SAMNP. One interviewee stated, "a strength for St Anne when it was designated over forty years ago, is now its main weakness: its proximity to Victoria". Today SAMNP is one of the most visited MPAs in the country among locals and tourists alike, yet very little is done to protect it from the impacts of tourism. The main impacting tourism activities include increased boat traffic due to island excursions, fish feeding, uncontrolled anchor damage to corals due to insufficient instalment of buoys, littering, shell extraction from beaches as well as coral breaking due to careless snorkelling and diving practices. Unsustainable tourism practices are partly due to lack of awareness and lack of recognition of regulations, most likely because of tourism operators, who do not inform visitors of park rules, resulting in failure to respect regulations. Visitors should be informed about SAMNP's ecology and history so that responsible behaviour can be encouraged. Furthermore, as with all Seychellois MPAs, SAMNP is not divided into zones, despite this being suggested by MPA residents decades ago. Because many different nonconsumptive uses occur in SAMNP, stakeholders and scientific professionals could collaborate to implement a zonation scheme, permitting different uses to protect critical areas, by controlling access, reducing the area needed for surveillance, respecting local customs while promoting education and monitoring opportunities [32]. Zoning is recommended by the IUCN's best practice on managing conflicts in MPAs and is generally considered the best way of managing multiple-use MPAs [33,34].

As mentioned, this study was completed September 2018, since when inevitably there have been further developments in the Seychelles. Construction activities linked to new tourism development in the Seychelles has recently been slowing down, due to the extension of a moratorium from 2015 prohibiting the construction of new large hotel projects until the end of 2020 [12]. However, new resorts approved before 2015 , will nonetheless add thousands of hotel rooms and increase pressures on the environment. A feasibility study on the state of tourism development in the Seychelles is currently underway, analysing how best to maintain a balance between sustainable tourism and economic growth. This study is yet to be published, but it is anticipated that establishing limits to tourism based on carrying capacity assessments, would be beneficial to all marine parks. As such, the government is aiming to decrease the reliance on tourism by supporting the growth of offshore financial, information and communication sectors, as well as renewable energy [1]. It has been repeatedly demonstrated that tourism can provide many benefits such as driving economic growth and supporting livelihoods, and should thus be carefully implemented to be able to support effective management of SAMNP. Instead of increasing tourism influx, a more effective approach could instead be to increase the expenditure per tourist by lengthening their stays or providing more local goods and services for purchase, as has been demonstrated by an abundance of studies [35]. Promoting ecotourism

Cockerell, L.M. and Jones, P. J. S. (in press) Governance Analysis of St Anne Marine National Park, Seychelles. Marine Policy, 103912. https://doi.org/10.1016/j.marpol.2020.103912. One of 20 papers in a special section on 28 case studies on MPA Governance. 
and conducting an accurate on-site carrying capacity study to respect the environmental fragility of the area, could help amplify sustainable socio-economic benefits from tourism in SAMNP.

\section{Governance approach}

The Seychelles Centre for Marine Research and Technology (SCMRT) was established in 2001 and transformed into Seychelles National Parks Authority (SNPA) in 2009, becoming a budget-dependent authority within MEECC. Today, SNPA is a parastatal organisation responsible for managing the Seychelles' state-owned national parks including SAMNP. SNPA oversee the MPA in a top-down approach following the second governance type described by the MPAG analysis framework, 'governed by the state with significant decentralisation and/or influences from private organisations' $[9,36]$. It is thus government-led but tending towards decentralisation as decisions are taken by the state but implementation and some decision-making is delegated to SNPA. The Board is appointed by the state and consists of SNPA's CEO, a Chairperson and representatives from the Ministry of Environment (MoE), Seychelles Tourism Board, Seychelles Fishing Authority, Seychelles Coast Guard, the Department of Education and the Seychelles Island Foundation [8]. The head of Marine Operations ensures objectives are met, designs the SAMNP programme and presents it to the Board for approval. Below him/her are the park officers who oversee ranger duties and training, while handling entrance fees collected by rangers who patrol the park, collect payments and are assisted by an assistant park officer. The structure of the organisation under the MoE is shown in Figure 4.

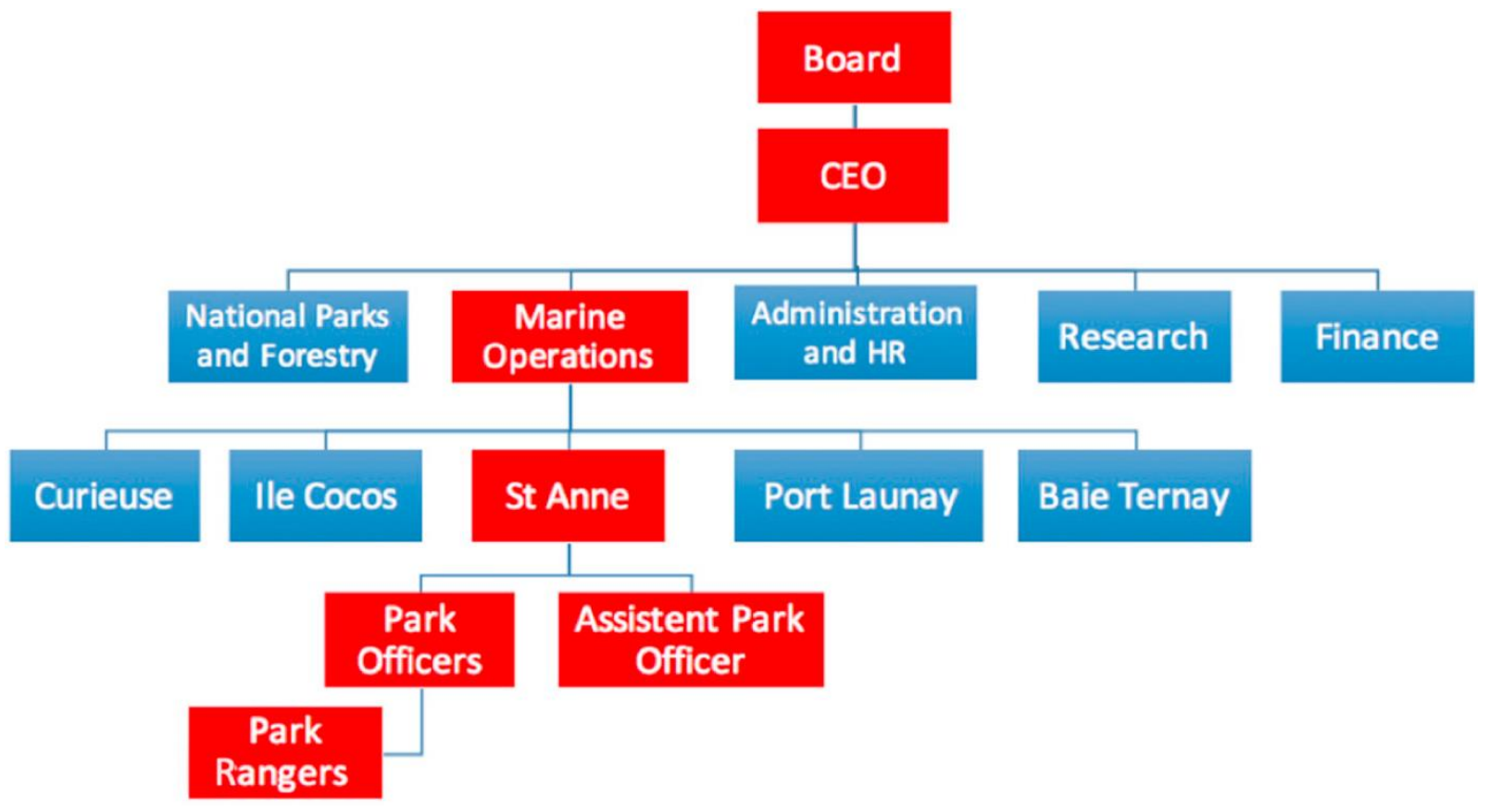

Figure 4. Organigram of SAMNP, adapted from [37].

The Board reports policy issues to the MoE, oversees finances, goals and the CEOs actions, and answers to the public and the National Assembly when required. However, due to the lack of meetings and publicly available information, stakeholders are generally neither involved nor informed in decision-making. Furthermore, a draft management plan was created for SAMNP in 1995 but was never officially approved, resulting in an absence of clear aims and objectives, uses and control measures from its very initiation.

Cockerell, L.M. and Jones, P. J. S. (in press) Governance Analysis of St Anne Marine National Park, Seychelles. Marine Policy, 103912. https://doi.org/10.1016/j.marpol.2020.103912. One of 20 papers in a special section on 28 case studies on MPA Governance. 
According to SNPAs strategic plan, the Marine Park Operations sub-unit of SNPA is responsible for the management of SAMNP, the implementation of management plans, enforcement and patrolling, visitor information and assistance, installation and maintenance of infrastructure, collection of marine park fees, assistance of research work and finally to support educational and awareness programmes [37]. During the study period, the income derived went straight to the central government in exchange for a yearly budget. However, SNPA were collecting more revenue than they were receiving from the government and their yearly budget allocation was insufficient to support effective management. In January 2019 SNPA became financially autonomous and now manages their own budgeting, but as of yet there is not much evidence of any major governance changes, which arguably is due to the early stages of the transformation.

\section{Effectiveness}

Drawing on the MPAG framework [9], an effectiveness score of 10 some impacts beginning to be slightly addressed', is assigned because it is evident that the current governance has limited effectiveness in addressing the threats to SAMNP. The lack of ranger enforcement capacity, coupled with weak institutional capacity, inadequate resources, limited political will and a tight budget makes the effectiveness of SAMNP very restricted. Its designation constituted little more than a 'paper park' as no management plan was formulated and thus, objectives, uses and regulations have never been clarified. Moreover, outdated legislations, weak penalties for deterrence and a general lack of awareness have resulted in high levels of non-compliance and a curtailed ability to achieve objectives. Due to the shortage of research and a baseline biodiversity evaluation, it is difficult to assess changes in biomass, fish density and coral cover inside SAMNP, but there is widespread recognition that many of the habitats have been degraded and various species locally extirpated, indicating that objectives are not being met. Numerous interviewees argued that SAMNP is 'dead,' having lost its colours and life, but nevertheless found it important to be maintained and hopefully restored. Another argued how SAMNP is the easiest marine park to manage due to its proximity to Mahé and the capital, suggesting that "If we cannot do it right here, I doubt they will be able to do it elsewhere... I think they should try to revive SAMNP at all costs to set an example for other parks". The overarching perspective of most interviewees was thus that SAMNP is ecologically, symbolically, culturally and historically important, and many people rely on it for their livelihoods, making it important to protect. SNPAs poor level of transparency and stakeholder-inclusion in decision-making has, however, resulted in marginalised and neglected community groups. SNPA claim they will initiate more meetings, signifying efforts toward addressing poor stakeholder involvement. SNPA have lacked the appropriate resources and capacities to address conflicts, but steps have recently been taken to begin addressing some impacts. SNPA's website is being updated, an annual kayaking event has been introduced, there are discussions around employing a communications officer to run a marketing and sales unit, and more buoys will soon be installed to clarify boundaries while reducing anchor damage on corals, which are all signs of at least partially addressing governance weaknesses. However, more communication efforts are needed to spread awareness and it is questionable when boundary marker buoys will be deployed, as installation appears to be both complicated and time-consuming. Additionally, an online entrance fee payment system is currently being implemented to separate rangers from revenue collection, but is not yet operational. The system is aimed at minimising revenue loss through non-collection and rangers misappropriating user fees, and increasing the capacity for enforcement by enabling rangers to increase patrolling, which could result in reduced poaching. SNPA claim they will reallocate finances to update facilities and equipment, produce publicly available annual reports and develop management plans for various state-owned MPAs, including SAMNP [11]. However, there have been limited efforts to minimise unsustainable tourism practices or increase research efforts, improve ranger training, establish collaborative platforms, promote the recognition of benefits or peer enforcement and as such, the proportion of conflicts currently addressed is low, hence the assignation of a low management effectiveness score. It should also be noted that SNPA have recently produced a marketing and communications plan (2019-2024) in order to increase and improve their communication outwards [8].

Cockerell, L.M. and Jones, P. J. S. (in press) Governance Analysis of St Anne Marine National Park, Seychelles. Marine Policy, 103912. https://doi.org/10.1016/j.marpol.2020.103912. One of 20 papers in a special section on 28 case studies on MPA Governance. 
Effectiveness is strongly influenced by governance and researchers agree that long-term MPA success is closely linked to the involvement and support of stakeholders and local communities in MPA selection, establishment and management [38,39]. It is argued therefore that protected areas must incorporate the concerns of society, where stakeholder knowledge and interests are integrated and actors can agree upon regulations and practices, conflict resolutions, negotiate trade-offs and share knowledge $[40,41]$. Moreover, studies have demonstrated that "... social networks can be more important than the existence of formal institutions for effective enforcement and compliance with environmental regulations" [42] p366. The degree of management effectiveness is thus arguably determined by the extent to which institutions reflect and address local socio-economic conditions (including livelihoods, poverty and equity), and that stakeholders therefore are more likely to comply with regulations if they are able to participate in decisionmaking processes $[24,43,44]$.

Interviewees revealed that despite the lack of transparency and collaborative opportunities, there is widespread interest among stakeholders to participate in decision-making processes and collaborate with SNPA. This could be interpreted as a recognition of the potential benefits derived from SAMNP, and of the ecological and cultural importance of preserving the area. However, as SNPA have not included the local community in the designation, planning or current management of SAMNP, there is a lack of support and trust for the managing body. SNPA have had a high CEO turnover which, according to interviewees, has made it difficult for stakeholders to establish meaningful relationships with SNPA, noting that SNPA has various partnerships in other MPAs, but none in SAMNP. Most stakeholders feel alienated from decision-making processes and are dissatisfied that their knowledge and interests have not been utilised or included, displaying a lack of support and trust and a sense of powerlessness and frustration. Interviewees explained how local and traditional knowledge is never incorporated into decision-making, despite them having extensive knowledge about the flora and fauna of the site. On the contrary, one interviewee argued that the lack of stakeholder engagement is more a reflection of the current political system rather than of what SNPA intend, as no national legislative requirement exists for involving stakeholders in protected area decisionmaking. Nonetheless, SNPA must realise the benefits of increased stakeholder involvement which requires re-strategising governance arrangements.

It is evident that SNPA's top-down approach is problematic as there is a lack of participation and knowledge incentives. Implementing a combination of governance approaches therefore, through shared control between government agencies (top-down), local communities (bottom-up) and market-forces, could offer significant benefits by empowering stakeholders while allowing the state to retain an appropriate amount of steer [36]. Case studies from Madagascar and New Guinea revealed that when local communities managed marine resources with minimal government and market interventions, results showed more abundant marine resources as well as improved compliance and enhanced conservation effectiveness $[6,45]$. Case studies from all around the world have shown evidence of local community involvement assisting in management effectiveness in different ways, and it can thus be argued that stakeholder involvement is beneficial for MPAs, and can even create a sense of ownership and pride among residents $[42,46]$.

\section{Incentives}

The incentives applied and additional incentives that are particularly important priorities to be strengthened or introduced to promote effective governance in SAMNP are summarised in Table 3. The numbers before each incentive are based on the numbered taxonomy of 36 incentives [36].

The incentives web [Figure 5] highlights that most incentives employed are economic and legal, signifying that the 'invisible hand' of economic rationality plays an important role in steering decisions alongside the

Cockerell, L.M. and Jones, P. J. S. (in press) Governance Analysis of St Anne Marine National Park, Seychelles. Marine Policy, 103912. https://doi.org/10.1016/j.marpol.2020.103912. One of 20 papers in a special section on 28 case studies on MPA Governance. 
state. Only two participation incentives are used while knowledge incentives are completely absent, demonstrating a lack of stakeholder-inclusion and reflecting the need for a more participatory bottom-up approach. Top-down governance approaches need strong legal incentives to reinforce legislation, yet only four legal incentives are used while two need introducing. All communication incentives are employed but all need strengthening. The government-led approach and the lack of stakeholder involvement are major factors limiting and defining which incentives are used. The incentives web therefore illustrates the need to employ a broader diversity of incentives (particularly participation and knowledge incentives), while strengthening all used incentives in order to create a resilient web of interconnected incentives from all categories to enhance effectiveness.

Table 3. Incentives applied in SAMNP. Incentives applied $(\mathrm{Y})$, including those that are particularly important priorities for strengthening $\left(\mathrm{Y}^{*}\right)$ and introducing $\left(\mathrm{N}^{*}\right)$.

\begin{tabular}{|c|c|c|}
\hline Incentive & Used & How/Why? \\
\hline $\begin{array}{l}\text { Economic } \\
\text { 3. Reducing the } \\
\text { leakage of } \\
\text { benefits }\end{array}$ & $\mathrm{Y}^{*}$ & $\begin{array}{l}\text { Many employment opportunities in the recreational and tourism sector are provided, } \\
\text { which are principally occupied by locals and MNP-residents, but increasingly also by } \\
\text { incoming corporate tourism developers, which is resulting in a leakage of benefits. } \\
\text { Artisanal fishermen may benefit from spill-over effects but the overall benefits of } \\
\text { SAMNP are too marginal to truly benefit local communities. There is an urgent need to } \\
\text { stop informal agreements from forming between rangers and tour operators, which is } \\
\text { resulting in a large user fee collection wastage. }\end{array}$ \\
\hline $\begin{array}{l}\text { 4. Promoting } \\
\text { profitable and } \\
\text { sustainable } \\
\text { fishing and } \\
\text { tourism }\end{array}$ & $\mathrm{N}^{*}$ & $\begin{array}{l}\text { Illegal fishing continues to be an issue due to poor enforcement and insufficient } \\
\text { penalties for deterrence. Strict laws should be implemented through a coordinated } \\
\text { agreement to prevent fishing activities from occurring. Well managed tourism could } \\
\text { also provide sustainable ways of non-consumptive resource exploitation and could } \\
\text { increase awareness of the benefits of SAMNP, while delivering economic benefits and } \\
\text { working towards conservation objectives. }\end{array}$ \\
\hline $\begin{array}{l}\text { 5. Promoting } \\
\text { green marketing }\end{array}$ & $\mathrm{N}^{*}$ & $\begin{array}{l}\text { There are some successful green tourism activities such as snorkelling trails, coral } \\
\text { nurseries, hiking trails, and events, while SAMNP hotels are also advertised as eco- } \\
\text { tourism destinations. Implementing a green marketing/certification system, while } \\
\text { increasing communication of SAMNPs environmental significance, could advance green } \\
\text { marketing. More importantly, there is a need to address the impacts of tourism } \\
\text { development, promote local participation in decision-making, reduce the leakage of } \\
\text { benefits etc., in order to make tourism more eco-friendly and increase the potential for } \\
\text { green marketing. }\end{array}$ \\
\hline $\begin{array}{l}\text { 6. Promoting } \\
\text { diversified and } \\
\text { supplementary } \\
\text { livelihoods }\end{array}$ & $\mathrm{Y}^{*}$ & $\begin{array}{l}\text { Tourism activities have been promoted as alternative livelihoods e. g. occupations in } \\
\text { glass-bottom boats and snorkelling tours, restaurants, hotels etc., but there is scope for } \\
\text { improvement due to e.g. marginalised fishermen. }\end{array}$ \\
\hline $\begin{array}{l}\text { 9. Provision of } \\
\text { state funding }\end{array}$ & $\mathrm{Y}^{*}$ & $\begin{array}{l}\text { There is a significant lack of both financial support and political will to provide for the } \\
\text { success of SAMNP, as much of the collected user fees appear to be absorbed by the } \\
\text { government rather than reinvested back into SAMNP. The lack of financing to employ } \\
\text { more rangers, update equipment, enable enforcement and more, is therefore a major } \\
\text { weakness. Since the completion of this research project,SNPA has become financially } \\
\text { autonomous, and as a result a larger proportion of the collected user fees will be } \\
\text { reinvested in management, paradoxically potentially making SAMNP better funded in } \\
\text { the absence of state funding by collecting and reinvesting user fee revenue. }\end{array}$ \\
\hline
\end{tabular}

Cockerell, L.M. and Jones, P. J. S. (in press) Governance Analysis of St Anne Marine National Park, Seychelles. Marine Policy, 103912. https://doi.org/10.1016/j.marpol.2020.103912. One of 20 papers in a special section on 28 case studies on MPA Governance. 


\begin{tabular}{|c|c|c|}
\hline $\begin{array}{l}\text { 10. Provision of } \\
\text { NGO, private } \\
\text { sector and user } \\
\text { fee funding }\end{array}$ & $\mathrm{Y}^{*}$ & $\begin{array}{l}\text { Visitor entrance fees, anchorage fees and overnight anchorage fees are collected. } \\
\text { Research suggests that tourists are willing to pay increased entrance fees as they have } \\
\text { not changed in almost a decade and are considerably less than in other protected areas } \\
\text { run by NGOs and the private sector [30]. Additionally, there is no system in place for } \\
\text { MNP hotel guests to pay entrance fees through e.g. a MNP tax or bed levy collected by } \\
\text { the hotels, and the potential of charging locals should also be explored. Scope to } \\
\text { identify new revenue streams and long-term funding from NGOs and the private sector. }\end{array}$ \\
\hline $\begin{array}{l}\text { Communication } \\
11 . \text { Raising } \\
\text { awareness }\end{array}$ & $Y^{*}$ & $\begin{array}{l}\text { The knowledge of SAMNP is low as there is only one outdated ( }>10 \text { years) brochure, } \\
\text { limited information on SNPA's website, few rarely updated social media accounts and } \\
\text { very few events. SAMNP has minimal media attention and the only way information is } \\
\text { spread, other than online, is along beaches by tour operators and hoteliers advertising } \\
\text { excursions. Scope to significantly increase awareness by initiating school campaigns } \\
\text { and visits, volunteering and outreach programs, tourist activities and workshops with } \\
\text { locals as this is currently all only done by the Cerf Island Conservation Program (CICP). } \\
\text { An information desk should also be set up at the Marine Charter dock, providing } \\
\text { information, maps etc. }\end{array}$ \\
\hline $\begin{array}{l}\text { 12. Promoting } \\
\text { recognition of } \\
\text { benefits }\end{array}$ & $\mathrm{Y}^{*}$ & $\begin{array}{l}\text { Tourism benefits are widely acknowledged and some fishermen also recognise the } \\
\text { benefits of spill-over into surrounding waters, arguing that improved enforcement and } \\
\text { stricter regulations are needed to enhance these benefits. However, more research and } \\
\text { monitoring could provide evidence of the success of NTZs, coral nursery projects and } \\
\text { more, which could increase awareness and create a sense of pride and recognition of } \\
\text { value among stakeholders. }\end{array}$ \\
\hline $\begin{array}{l}\text { 13. Promoting } \\
\text { recognition of } \\
\text { regulations and } \\
\text { restrictions }\end{array}$ & $\mathrm{Y}^{*}$ & $\begin{array}{l}\text { Rules are vaguely communicated through SNPA's website and sometimes through tour } \\
\text { operators. Increased tourism magnifies the importance of recognition of regulations to } \\
\text { promote compliance. Additionally, SAMNP boundaries are poorly marked with } \\
\text { insufficient buoys and old equipment. Scope to significantly raise awareness of } \\
\text { regulations among all users. }\end{array}$ \\
\hline $\begin{array}{l}\text { Knowledge } \\
14 . \text { Promoting } \\
\text { collective learning }\end{array}$ & $\mathrm{N}^{*}$ & $\begin{array}{l}\text { The lack of stakeholder inclusion in SAMNP limits the potential for collective learning } \\
\text { between local users with traditional knowledge, and 'expert' scientists. Scientific } \\
\text { knowledge dominates over traditional knowledge since the knowledge and opinions of } \\
\text { the local community have never been incorporated into decision-making. Scope to } \\
\text { increase collaborative research and monitoring between constituencies to promote } \\
\text { collective learning. }\end{array}$ \\
\hline $\begin{array}{l}\text { Legal } \\
\text { 18. Capacity for } \\
\text { enforcement }\end{array}$ & $\mathrm{Y}^{*}$ & $\begin{array}{l}\text { Surveillance and enforcement are hampered by the lack of experienced rangers, run } \\
\text { down infrastructure, insufficient funding, lack of technological applications and the lack } \\
\text { of political will. Rangers 'patrol' during daytime but primarily collect entrance fees, } \\
\text { enabling poaching activities to continue. Scope to employ more rangers, improve their } \\
\text { training and explore additional opportunities to improve enforcement. }\end{array}$ \\
\hline $\begin{array}{l}\text { 19. Penalties for } \\
\text { deterrence }\end{array}$ & $\mathrm{Y}^{*}$ & $\begin{array}{l}\text { Some penalties exist but are insufficient deterrents. Infringements are typically } \\
\text { undetected or dismissed due to their inadequacy, or the wrongdoer's ability to contact } \\
\text { a political friend or relation to have the infringement dropped. Scope to increase } \\
\text { penalties, renew and clarify regulations and increase willingness to fairly impose the } \\
\text { law. }\end{array}$ \\
\hline $\begin{array}{l}\text { 21. Attaching } \\
\text { conditions to use } \\
\text { and property } \\
\text { rights, }\end{array}$ & $\mathrm{N}^{*}$ & $\begin{array}{l}\text { Requirements for tour boats exist but it is doubtful whether they are being complied } \\
\text { with fully. It is clear however, that illegal fishing occurs and that recreational boats do } \\
\text { not comply with regulations. Devolving responsibilities to other organisations could } \\
\text { benefit SNPA and involve steering towards a more inclusive and locally-tailored } \\
\text { management. }\end{array}$ \\
\hline
\end{tabular}

Cockerell, L.M. and Jones, P. J. S. (in press) Governance Analysis of St Anne Marine National Park, Seychelles. Marine Policy, 103912. https://doi.org/10.1016/j.marpol.2020.103912. One of 20 papers in a special section on 28 case studies on MPA Governance. 


\begin{tabular}{|c|c|c|}
\hline $\begin{array}{l}\text { decentralisation, } \\
\text { etc. }\end{array}$ & & \\
\hline $\begin{array}{l}\text { 22. Cross- } \\
\text { jurisdictional } \\
\text { coordination }\end{array}$ & $\mathrm{Y}^{*}$ & $\begin{array}{l}\text { SNPA's lack of collaboration with other authorities, organisations and stakeholder } \\
\text { groups is restricting SAMNPs effectiveness. Scope to promote partnerships across } \\
\text { jurisdictions to prevent illegalities and promote cooperation across sectoral } \\
\text { jurisdictions, particularly planning decisions related to tourism developments, but } \\
\text { limitations exist in both financial resources and political will. Greater cooperation and } \\
\text { clarification of roles with MEECC would also be beneficial. }\end{array}$ \\
\hline $\begin{array}{l}\text { 23. Clear and } \\
\text { consistent legal } \\
\text { definitions }\end{array}$ & $\mathrm{Y}^{*}$ & $\begin{array}{l}\text { The legal basis for SAMNP has been established as an appendix to the National Parks } \\
\text { and Nature Conservancy Act, 1969,1975 [47], but is insufficient, outdated and } \\
\text { ineffectively enforced. Also, due to the lack of an official management plan, objectives, } \\
\text { restrictions, and responsibilities have never been clarified. Scope to clarify legislations } \\
\text { and policies across all relevant sectors. }\end{array}$ \\
\hline $\begin{array}{l}\text { 26.Transparency, } \\
\text { accountability } \\
\text { and fairness }\end{array}$ & $\mathrm{N}^{*}$ & $\begin{array}{l}\text { There is a lack of transparency to and inclusion of parties outside SNPAs decision- } \\
\text { making. Limited public access to information and few public consultations means that } \\
\text { locals are uninformed about how funds are allocated, resulting in mistrust and lack of } \\
\text { support. A clear reporting strategy is needed to ensure transparent and fair } \\
\text { communication to the public. }\end{array}$ \\
\hline $\begin{array}{l}\text { Participation } \\
\text { 27. Rules for } \\
\text { participation }\end{array}$ & $\mathrm{N}^{*}$ & $\begin{array}{l}\text { There are no clear rules for the participation of stakeholders in decision-making, yet } \\
\text { rules are necessary to clarify and formalise the roles and responsibilities of actors and } \\
\text { ensure increased involvement. }\end{array}$ \\
\hline $\begin{array}{l}\text { 28. Establishing } \\
\text { collaborative } \\
\text { platforms }\end{array}$ & $\mathrm{N}^{*}$ & $\begin{array}{l}\text { SAMNPs top-down approach does not allow for collaborative opportunities. An } \\
\text { advisory board should be set up to initiate a collaborative platform representing } \\
\text { stakeholders in open discussions, through regular meetings, workshops and community } \\
\text { programs, enabling stakeholders to influence decision-making. Interviewees indicated } \\
\text { a strong wish for more participation amongst locals. }\end{array}$ \\
\hline $\begin{array}{l}\text { 31. Decentralising } \\
\text { responsibilities }\end{array}$ & $\mathrm{Y}^{*}$ & $\begin{array}{l}\text { Many responsibilities are decentralised to SNPA whilst the government retains the } \\
\text { principal decision-making powers. Devolving more responsibilities to local } \\
\text { organisations/agencies, particularly to SNPA, could be highly beneficial in promoting a } \\
\text { more collaborative and locally-tailored approach. }\end{array}$ \\
\hline $\begin{array}{l}\text { 32. Peer } \\
\text { enforcement }\end{array}$ & $\mathrm{Y}^{*}$ & $\begin{array}{l}\text { MNP-residents contact rangers regarding infringements, but many are reluctant to do } \\
\text { so due to fear of the offenders. Peer enforcement is also undermined by informal } \\
\text { agreements between rangers and select locals. Promoting volunteering opportunities } \\
\text { or appointing honorary wardens could improve surveillance and promote the sense of } \\
\text { ownership among stakeholders. }\end{array}$ \\
\hline $\begin{array}{l}\text { 33. Building trust } \\
\text { and the capacity } \\
\text { for cooperation }\end{array}$ & $\mathrm{N}^{*}$ & $\begin{array}{l}\text { There is little involvement of stakeholders as there is no statutory requirement for } \\
\text { involving local communities in decision-making processes in MPAs in the Seychelles. } \\
\text { Trust and support need to be considerably reconstructed. Strategically establishing } \\
\text { links between SNPA and key stakeholder representatives could help build trust and } \\
\text { capacity for cooperation. }\end{array}$ \\
\hline $\begin{array}{l}\text { 35. Building on } \\
\text { local customs }\end{array}$ & $\mathrm{N}^{*}$ & $\begin{array}{l}\text { Local customs are typically ignored and MNP-residents' knowledge never utilised. } \\
\text { There are also outdated legislations on permitted fishing methods in SAMNP which has } \\
\text { led to great confusion. There needs to be recognition and protection of local traditions } \\
\text { and uses and equitable sharing of benefits. }\end{array}$ \\
\hline
\end{tabular}

Cockerell, L.M. and Jones, P. J. S. (in press) Governance Analysis of St Anne Marine National Park, Seychelles. Marine Policy, 103912. https://doi.org/10.1016/j.marpol.2020.103912. One of 20 papers in a special section on 28 case studies on MPA Governance. 


\section{Cross-cutting themes}

\subsection{Role of leadership}

There are many advocates for SAMNP, but there is a lack of leadership from SNPA and other authorities to address conflicts. The lack of financial and technical support coupled with national limitations, corruption, high staff-turnover and the constant replacing of CEOs, has not ameliorated the situation, resulting in limited trust and local support. The absence of commitment and drive is arguably a major factor undermining effectiveness.

\subsection{Role of NGOs}

NGOs play an important role in SAMNP but have no decision-making power. The Marine Conservation Society Seychelles (MCSS) and SNPA collaborated to create snorkelling trails around Cerf Island which were very successful, resulting in investment and donations from many Cerf Island hotels and private persons. The Cerf Island Conservation Program (CICP) was consequently set up through a public-private partnership in 2015 between MCSS and hotels located inside SAMNP, becoming the only environmental NGO dedicated to the conservation and sustainable use of marine resources inside SAMNP. CICP is responsible for most if not all the conservation activities in the site, such as creating coral nurseries, undertaking scientific research and monitoring, collecting knowledge, promoting ecotourism, creating hiking trails, running beach cleans, creating information panels and maps, organising events and volunteering opportunities and more. CICP have raised awareness and interest among both visitors and MPA residents, which has generated a strong relationship with the Cerf Island community who now actively cooperate with $\mathrm{CICP}$, creating a sense of ownership among them. CICP are the only NGO working on coral research in SAMNP, and whilst the strong role played by NGOs is welcomed, it is not a substitute for the important roles of the state. On a larger scale, the Seychelles have designated almost a third of its ocean area for protection from commercial fishing, oil exploration and other large-scale developments, in return for a deal relieving it from some of its sovereign debt. The Nature Conservancy (TNC) has negotiated a debt-for-nature deal to convert sovereign debt repayments into conservation funding, committing to marine spatial planning while expanding the nation's protected area from less than $1 \%$ to $30 \%$. This debt swap is aimed at conserving critical biodiversity, building resilience against climate change and benefiting the people of the Seychelles [48].

\subsection{Equity issues}

Costs and benefits are not equitably shared since many fishermen and MPA residents feel marginalised as they are excluded from the management of the NTZ whilst tourism income booms. Social justice issues have arisen whereby fishermen and MPA residents have been forced to fish outside SAMNP, despite having fished there all their lives, implying raised fuel costs and navigational risks for travelling further distances to less productive fishing grounds, while other economic activities continue unchanged. Many locals therefore have limited or no sense of ownership over SAMNP. Moreover, tourism impacts on the site are of great concern to many locals, as some benefit from employment opportunities, while others only experience the costs e.g. littering. Procedural equity is undermined by the lack of local participation in decision-making and there is also little recognition of traditional customs or ways of life.

\section{Discussions}

The governance of SAMNP has proved to be largely ineffective because of numerous conflicts and the need to introduce or strengthen many incentives. SAMNPs low capacity for enforcement i.e. ensuring sufficient state capacity, political will, surveillance and financial support to enable equitable and effective enforcement of regulations, is undoubtedly one of its major weaknesses. These constraints have previously also been

Cockerell, L.M. and Jones, P. J. S. (in press) Governance Analysis of St Anne Marine National Park, Seychelles. Marine Policy, 103912. https://doi.org/10.1016/j.marpol.2020.103912. One of 20 papers in a special section on 28 case studies on MPA Governance. 
identified as among the most frequently cited incentives needed to improve effectiveness [49]. Hence, SAMNPs low capacity for enforcement, paired with the other conflicts discussed, is impeding its ability to effectively achieve objectives. When interviewees were asked about the management of SAMNP, answers ranged from "what marine national park? This isn't a MPA. It is not managed at all!" to "SNPA aren't doing anything in conservation, it has just become a tourism business. There has not been enough political will to be serious about running MPAs here."

The consensus among interviewees was clear: SAMNP is neglected by the government, lacks adequate resources and capacities and cannot therefore achieve its objectives. According to most respondents, SNPAs priority is to increase revenue, which has driven decision-making at the cost of conservation objectives. Interviewees strongly indicated that the objective of protecting marine species and habitats from harmful disturbances is not being met as many uncontrolled uses, particularly related to tourism, are impacting the marine environment. Accordingly, the uses of the park are not effectively managed as the achievement of objectives is not incorporated into daily operational management. Few interviewees knew anything about the management of SAMNP and no SNPA Board members responded to requests to be interviewed for this research. No annual reports are published and SNPA's Strategic Plan 2017-2021 completely sidesteps the Board, its members, minutes and activities, signifying that benefits are not publicly demonstrated. It was therefore frequently argued that the governance of SAMNP is too top-down, undermining many participation and knowledge incentives as illustrated in the incentives-web [Figure 5]. The current governance approach uses some economic, communication and legal incentives, but legal incentives, enforcement (I-18), deterrence capacity (I-19) and related support that only the state can provide, remain insufficient. Based on past case-studies, many neo-institutionalist researchers advocate for more bottom-up governance, agreeing that top-down approaches alone tend to be ineffective in achieving objectives [36,50], and in meeting the needs of communities in developing countries due to financial and human resource constraints [51,52]. It is recognised that some degree of top-down control is necessary to achieve conservation objectives, but that there is a risk of becoming too top-down if the state assumes a solitary controlling role and overlooks stakeholder participation. In summary, SNPA's management structure is weak in terms of both top-down legal and bottom-up participatory incentives, as it appears to have imposed excessively top-down management structures and must therefore adapt to greater institutional reflexivity and flexibility to overcome their "bureaucratic impulse to retain central authority" [53]. Hence, a combination of top-down, bottom-up and market-based approaches, through co-evolutionary hierarchical governance [36] could assist in enhancing effectiveness, in combination with increased partnerships.

\section{Conclusions}

The aim of this study has been to analyse the governance effectiveness of SAMNP by applying the MPAG analysis framework, determine its main conflicts, drivers and mitigation methods, and explore if locals are incorporated into its governance. Hence, in agreement with Rife et al. that the mere establishment of an MPA does not guarantee its success [54], findings revealed that the governance of SAMNP proved largely ineffective in controlling uses to protect marine habitats and of awareness and limited recognition of regulations and benefits, combined with economic development pressures and other national constraints, has contributed to the accumulation of a myriad of conflicts and related impacts, making a re-evaluation of governance necessary. The primary conflicts identified are poaching, coastal development and unsustainable tourism practices, with the lack of state capacity, political will and capacity for enforcement as major governance weaknesses. These conflicts and weaknesses are obstructing the achievement of objectives and severely undermining effectiveness while resulting in adverse environmental impacts to SAMNP. Few mitigation methods for addressing these conflicts are in place, indicating that many incentives need strengthening and/or introducing to successfully address conflicts.

Cockerell, L.M. and Jones, P. J. S. (in press) Governance Analysis of St Anne Marine National Park, Seychelles. Marine Policy, 103912. https://doi.org/10.1016/j.marpol.2020.103912. One of 20 papers in a special section on 28 case studies on MPA Governance. 


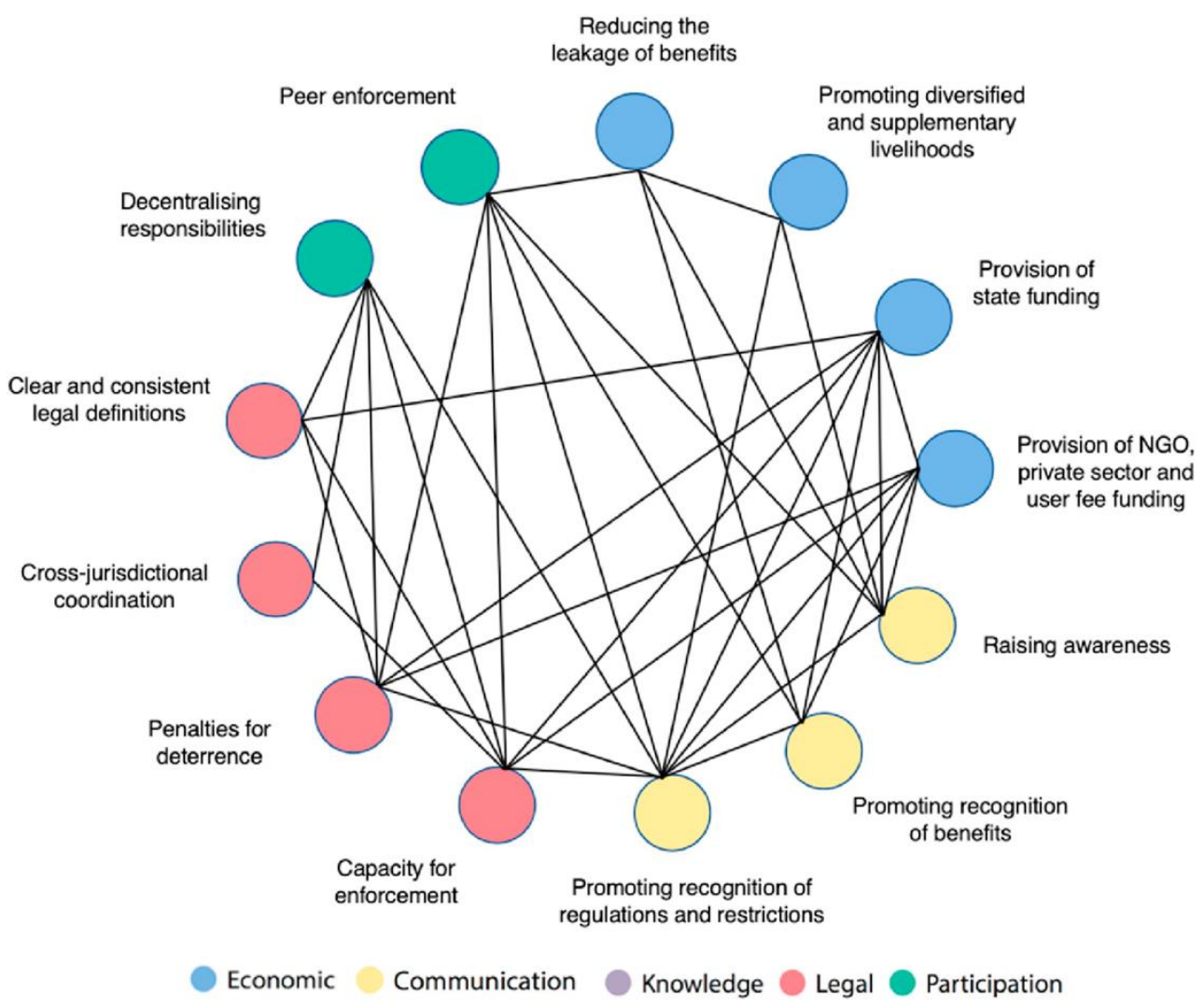

Figure 5. Current SAMNP incentives web.

Findings suggest that stakeholder involvement is severely lacking in SAMNP, as locals are excluded from decision-making processes. This implies a shortage of participation and knowledge incentives which is contributing to the ineffectiveness of the site. Therefore, the outcomes of this study resonate with findings from previous MPAG case-studies, that there is a need for MPAs to steer away from separated governance approaches (bottom-up, top-down or market steer) and instead navigate towards integrated solutions whereby different governance approaches coevolve and support each other [36,55]. It is argued that the success of SAMNP will ultimately depend on stakeholder support and the ability to influence the behaviour of users, and that therefore, increased support from a more participatory, bottom-up governance approach is needed to ensure the inclusion of both local and state control in decision-making, alongside strengthened enforcement and deterrence. These findings also support the argument that 'resilience through diversity' is achieved not only through the collaboration between state and local actors, but also through the usage of a range of different incentives from all incentives categories $[36,56]$. The governance transition will presumably represent major policy changes, but substantial management changes are needed if SNPA is to succeed in effectively governing the site. If implemented well, SAMNP could even serve as an example to other MPAs facing similar issues elsewhere, particularly other SIDS. Potential future research could therefore be to repeat an in-depth governance study of SAMNPs effectiveness in 3-10 years, to investigate whether any advances have been implemented, particularly as a result of the reform in 2019 making SNPA financially autonomous, recognising that this could help address or potentially exacerbate many of the pressing challenges.

\section{Declaration of competing interest}

None.

Cockerell, L.M. and Jones, P. J. S. (in press) Governance Analysis of St Anne Marine National Park, Seychelles. Marine Policy, 103912. https://doi.org/10.1016/j.marpol.2020.103912. One of 20 papers in a special section on 28 case studies on MPA Governance. 


\section{Acknowledgements}

We would like to express our gratitude to all the interviewees who participated in this study and shared their perspectives and thoughts, while making the first author feel very welcome and comfortable during her stay in the Seychelles. We are also grateful to two peer reviewers who provided valuable feedback and suggested revisions to this manuscript.

\section{References}

[1] CIA (Central Intelligence Agency), The world fact book (2020) Seychelles [Online] Available from: https://www.cia.gov/library/publications/the-world-factboo k/geos/se.html . (Accessed 26 January 2020).

[2] GoS, Government of Seychelles, Fifth National Report to the United Nations Convention on Biological Diversity, Ministry of Environment and Energy, Botanical Gardens, Mont Fleuri, Victoria, Republic of Seychelles, 2014. P.O. Box 445.

[3] J. Robinson, R. Aumeeruddy, M. Isidore, R. Payet, M. Marguerite, M. Laval, G. Domingue, V. Lucas, Country review: Seychelles. Review of the state of world marine capture fisheries management: Indian Ocean, FAO Fisheries Technical Paper (488), (2006) 425-435.

[4] R. Payet, W. Agricole, Climate change in the Seychelles: implications for water and coral reefs, AMBIO A J. Hum. Environ. 35 (4) (2006) 182-189.

[5] R. Baker, Scale and administrative performance: the governance of small states and microstates, in: R. Baker (Ed.), Public Administration in Small and Island States, Kumarian Press, West Hartford, CT, 1992, pp. 5-25.

[6] J. Francis, A. Nilsson, D. Waruinge, Marine protected areas in the Eastern African region: how successful are they? AMBIO A J. Hum. Environ. 31 (7) (2002) 503-511.

[7] J. Clifton, M. Etienne, D.K.A. Barnes, R.S.K. Barnes, D.J. Suggett, D.J. Smith, Marine conservation policy in Seychelles: current constraints and prospects for improvement, Mar. Pol. 36 (3) (2012) 823-831.

[8] SNPA (Seychelles National Parks Authority), St. Anne, 2018 [Online] Available from: http://www.snpa.gov.sc/marine-parks/st-anne. (Accessed 15 August 2018).

[9] Jones P. J. S. and Long S. (in prep) Introduction/Discussion paper.

[10] N. Prasad, N. Hypher, M. Gerecke, Seeing Big: Transformative Social Policies in Small States, UNRISD Research Paper, 2013, 2013-3, July.

[11] D. Philpot, T.S. Gray, S.M. Stead, Seychelles, a vulnerable or resilient SIDS? A local perspective, I. Stud. J. 10 (1) (2015) 33-48.

[12] World Bank, The world bank in Seychelles [Online] Available from: https://www.worldbank.org/en/country/seychelles/overview, 2019. (Accessed 26 January 2020).

[13] Human Development Report 2019, Inequalities in Human Development in the 21st Century, Briefing note for countries on the 2019 Human Development Report, 2019. (Accessed 6 March 2020).

Cockerell, L.M. and Jones, P. J. S. (in press) Governance Analysis of St Anne Marine National Park, Seychelles. Marine Policy, 103912. https://doi.org/10.1016/j.marpol.2020.103912. One of 20 papers in a special section on 28 case studies on MPA Governance. 
[14] C. Sheppard, D.J. Dixon, M. Gourlay, A. Sheppard, R. Payet, 'Coral mortality increases wave energy reaching shores protected by reef flats: examples from the Seychelles', Estuarine, Coastal and Shelf Sci. 64 (2-3) (2005) 223-234.

[15] J. Nevill, J. Prescott, N. Jivan Shah, M. Jeremie, Seychelles' National Biodiversity Strategy and Action Plan 2015-2020, 2014.

[16] SIF, Seychelles islands foundation newsletter 2017 (52) (2017). April.

[17] C.T. Perry, L. Alvarez-Filip, N.A.J. Graham, P.J. Mumby, S.K. Wilson, P.S. Kench, D.P. Manzello, K.M. Morgan, A.B.A. Slangen, D.P. Thomson, F. Januchowski- Hartley, S.J. Smithers, R.R. Steneck, R. Carlton, E.E. Edinger, I.C. Enochs, N. Estrada-Saldívar, M.D.E. Haywood, G. Kolodziej, G.N. Murphy, E. Pérez-Cervantes, A. Suchley, L. Valentino, R. Boenish, M. Wilson, C. Macdonald, Loss of coral reef growth capacity to track future increases in sea level, Nature 558 (7710) (2018) 396-400.

[18] N.A.J. Graham, T.R. McClanahan, M.A. MacNeil, S.K. Wilson, N.V.C. Polunin, S. Jennings, P. Chabanet, S. Clark, M.D. Spalding, Y. Letourneur, L. Bigot, R. Galzin, M.C. Ohman, K.C. Garpe, A.J. Edwards, C.R.C. Sheppard, Climate warming, marine protected areas and the ocean-scale integrity of coral reef ecosystems, PloS One 3 (8) (2008), e3039.

[19] N.A. Graham, S. Jennings, M.A. MacNeil, D. Mouillot, S.K. Wilson, Predicting climate-driven regime shifts versus rebound potential in coral reefs, Nature 518 (2015) 94-97.

[20] S.C. Jameson, M.H. Tupper, J.M. Ridley, The three screen doors: can marine "protected" areas be effective? Mar. Pollut. Bull. 44 (2002) 1177-1183.

[21] V. Hargreaves-Allen, S. Mourato, J. Milner-Gulland, A global evaluation of coral reef management performance: are MPAs producing conservation and socio-economic improvements? Environ. Manag. 47 (2011) 684-700.

[22] T.R. McClanahan, N.A. Muthiga, A.T. Kamukuru, H. Machano, R. Kiambo, The effects of marine parks and fishing on the coral reefs of northern Tanzania, Biol. Conserv. 89 (1999) 161-182.

[23] J.E. Byers, E.G. Noonburg, Poaching, enforcement, and the efficacy of marine reserves, Ecol. Appl. 17 (2007) 1851-1856.

[24] B.J. Bergseth, Effective marine protected areas require a sea change in compliance management, ICES (Int. Counc. Explor. Sea) J. Mar. Sci. 75 (3) (2017) 1178-1180.

[25] A. Balmford, T. Whitten, Who should pay for tropical conservation, and how could the costs be met? Oryx 37 (2) (2003) 238.

[26] A. Keane, J.P.G. Jones, G. Edwards-Jones, E.J. Milner-Gulland, The sleeping policeman: understanding issues of enforcement and compliance in conservation, Anim. Conserv. 11 (2) (2008) 75-82.

[27] K.L.F. Davis, G.R. Russ, D.H. Williamson, R.D. Evans, Surveillance and poaching on inshore reefs of the great barrier reef marine park, Coast. Manag. 32 (2004) 373-387.

[28] S.F. Walmsley, A.T. White, Influence of social, management and enforcement factors on the long-term ecological effects of marine sanctuaries, Environ. Conserv. 30 (2003) 388-407.

Cockerell, L.M. and Jones, P. J. S. (in press) Governance Analysis of St Anne Marine National Park, Seychelles. Marine Policy, 103912. https://doi.org/10.1016/j.marpol.2020.103912. One of 20 papers in a special section on 28 case studies on MPA Governance. 
[29] S.R. Floeter, B.S. Halpern, C.E.L. Ferreira, Effects of fishing and protection on Brazilian reef fishes, Biol. Conserv. 128 (2006) 391-402.

[30] Rylance, Visitor Willingness to Pay for Entrance to Seychelles Protected Areas, GoS-UNDP-GEF, Victoria, 2016.

[31] C.M. Pickering, W. Hill, Impacts of recreation and tourism on plant biodiversity and vegetation in protected areas in Australia, J. Environ. Manag. 85 (2007) 791-800.

[32] E. Taylor, M. Baine, A. Killmer, M. Howard, Seaflower marine protected area: governance for sustainable development, Mar. Pol. 41 (2013) 57-64.

[33] G. Kelleher, Guidelines for Marine Protected Areas, IUCN, Gland, Switzerland and Cambridge, UK, 1999, p. 107. Xxiv p.

[34] J. Day, Zoning - lessons from the Great Barrier Reef Marine Park, Ocean Coast. Manag. 45 (2-3) (2002) 139-156.

[35] A. Spenceley, Tourism Product Development Interventions and Best Practices in Sub-saharan Africa: Part 1: Synthesis, Report to the World Bank Tourism Industry: Research and Analysis Phase II, Nelspruit, 2010.

[36] P.J.S. Jones, Governing Marine Protected Areas: Resilience Through Diversity, Earth Scan from Routledge, London and New York, 2014. https://doi.org/10.4324/9780203126295

[37] Seychelles National Parks Authority Strategic Plan 2017-2021, 2017. (Accessed 5 March 2020). [38] C.H. Hard, K.R. Hoelting, P. Christie, R.B. Pollnac, Collaboration, legitimacy, and awareness in puget sound MPAs, Coast. Manag. 40 (3) (2012) 312-326. [39] R. Kelly, G.T. Pecl, A. Fleming, Social licence in the marine sector: a review of understanding and application, Mar. Pol. 81 (2017) 21-28.

[40] C. Folke, T. Hahn, P. Olsson, J. Norberg, Adaptive governance of social-ecological systems, Annu. Rev. Environ. Resour. 15 (30) (2005) 441-473.

[41] R. Pomeroy, F. Douvere, The engagement of stakeholders in the marine spatial planning process, Mar. Pol. 32 (2008) 816-822.

[42] Ö. Bodin, B. Crona, The role of social networks in natural resource governance: what relational patterns make a difference? Global Environ. Change 19 (3) (2009) 366-374.

[43] G. Epstein, Local rulemaking, enforcement and compliance in state-owned forest commons, Ecol. Econ. 131 (2017) 312-321.

[44] J.E. Cinner, Designing marine reserve to reflect local socioeconomic conditions: lessons from longenduring customary management systems, Coral Reefs 26 (2007) 1035-1045.

[45] T. McClanahan, M.J. Marnane, J.E. Cinner, W.E. Kiene, A comparison of marine protected areas and alternative approaches to coral- reef management', Curr. Biol. 16 (2006) 1408-1413.

Cockerell, L.M. and Jones, P. J. S. (in press) Governance Analysis of St Anne Marine National Park, Seychelles. Marine Policy, 103912. https://doi.org/10.1016/j.marpol.2020.103912. One of 20 papers in a special section on 28 case studies on MPA Governance. 
[46] H. Nava, M.T. Teresa Ramírez-Herrera, 'Government conservation policies on Mexican coastal areas: is "top-down" management working? Rev. Biol. Trop. 59 (4) (2011) 1487-1501.

[47] Seylii, National Parks and Nature Conservancy Act, 2018 [Online]. Available from: https://seylii.org/sc/legislation/consolidated-act/141 (Accessed 22 August 2018).

[48] J.J. Silver, M. Campbell, Conservation, development and the blue frontier: the republic of Seychelles' debt restructuring for marine conservation and climate adaptation Program, Int. Soc. Sci. J. (2018) 1-16. John Wiley \& Sons Ltd.

[49] P.J.S. Jones, E.M. De Santo, W. Qiu, O. Vestergaard, Introduction: an empirical framework for deconstructing the realities of governing marine protected areas, Mar. Pol. 41 (2013) 1-4.

[50] R.E. Johannes, Government-supported, village-based management of marine resources in Vanuatu, Ocean Coast Manag. 40 (2-3) (1998) 165-186.

[51] C. Camargo, J.H. Maldonado, E. Alvarado, R. Moreno- Sánchez, S. Mendoza, N. Manrique, A. Mogollón, J.D. Osorio, A. Grajales, J.A. Sánchez, Community involvement in management for maintaining coral reef resilience and biodiversity in southern Caribbean marine protected areas, Biodivers. Conserv. 18 (2009) 935-956.

[52] K. Stamieszkin, J. Wielgus, R.L. Gerber, Management of a marine protected area for sustainability and conflict resolution: lesson from Loreto bay national park (Baja California Sur, Mexico), Ocean Coast Manag. 52 (2009) 449-458.

[53] M.W. Murphree, The role of institutions in community-based conservation, in: D. Western, R.M. Wright, S.C. Strum (Eds.), Natural Connections: Perspectives in Community-Based Conservation, Island Press, Washington DC, 1994, pp. 403-427.

[54] A.N. Rife, B. Erisman, A. Sanchez, O. Aburto-Oropeza, When good intentions are not enough... Insights on networks of "paper park" marine protected areas, Conserv. Lett. 6 (2012) 200-212.

[55] B.J. McCay, P.J.S. Jones, Marine protected areas and the governance of marine ecosystems and fisheries, Conserv. Biol. 25 (2011) 1130-1133.

[56] P.J.S. Jones, W. Qiu, E.M. De Santo, Governing marine protected areas: social-ecological resilience through institutional diversity, Mar. Pol. 41 (2013) 5-13.

Cockerell, L.M. and Jones, P. J. S. (in press) Governance Analysis of St Anne Marine National Park, Seychelles. Marine Policy, 103912. https://doi.org/10.1016/j.marpol.2020.103912. One of 20 papers in a special section on 28 case studies on MPA Governance. 